\title{
DIVISION OFFICERS
}

President: Eileen Thornton, Oberlin College, Oberlin, Ohio.

Vice President and President Elect: Lewis C. Branscomb, Ohio State University, Columbus, Ohio.

Past President: Robert W. Orr, Iowa State College, Ames, Iowa.

Directors at LaRge: Elizabeth Findly, University of Oregon, Eugene, Oregon (1960); Mrs. Mary Manning Cook, Mills College, Oakland, California (1959); William S. Dix, Princeton University, Princeton, New Jersey (1958).

\section{COLLEGE LIBRARIES SECTION}

Chairman: Martha L. Biggs, Lake Forest College, Lake Forest, Illinois.

Vice Chairman and Chairman Elect: Edward C. Heintz, Kenyon College, Gambier, Ohio.

Secretary: Esther M. Hile, University of Redlands, Redlands, California.

Director: Sarah D. Jones, Goucher College, Baltimore, Maryland (1958).

\section{JUNIOR COLLEGE LIBRARIES SECTION}

Chairman: Mrs. Lula K. Pratt, Connors State Agricultural College, Warner, Oklahoma.

Vice Chairman and Chairman Elect: Orlin C. Spicer, J. Sterling Morton High School and Junior College, Cicero, Illinois.

Secretary: William K. Grainger, Bakersfield College, Bakersfield, California.

Director: Lottie M. Skidmore, Joliet Junior College, Joliet, Illinois (1960).

\section{PURE AND APPLIED SCIENCE SECTION}

Chairman: Edward A. Chapman, Rensselaer Polytechnic Institute, Troy, New York.

Vice Chairman and Chairman Elect: Carson W. Bennett, Rose Polytechnic Institute, Terre Haute, Indiana.

SECRETARY: Esther Schlundt, Purdue University, Lafayette, Indiana.

Director: H. Dean Stallings, North Dakota Agricultural College, Fargo, North Dakota (1960).

\section{TEACHER EDUCATION LIBRARIES SECTION}

Chairman: Walfred Erickson, Eastern Michigan College, Ypsilanti, Michigan.

Secretary and Chairman Elect: Gertrude W. Rounds, New York State Teachers College, Oneonta, New York.

Director: Mildred Herrick, Western Washington College of Education, Bellingham, Washington (1958). 


\section{UNIVERSITY LIBRARIES SECTION}

Chairman: Robert H. Muller, University of Michigan, Ann Arbor, Michigan.

Vice Chairman and Chairman Elect: Carl W. Hintz, University of Oregon, Eu gene, Oregon.

Secretary: Charlotte K. Anderson, University of New Hampshire, Durham, New Hampshire.

Director: Leonard H. Kirkpatrick, University of Utah, Salt Lake City, Utah.

\section{REPRESENTATIVES ON ALA COUNCIL}

From the candidates for ALA Council nominated by the ACRL Nominating Committee the following have been elected: For the term 1957-59: JoHN W. Ottemiller, Yale University, New Haven, Connecticut; Fleming Bennetr, University of Arizona, Tucson, Arizona; Robert R. Hertel, State Teachers College, Cortland, New York; and Constance M. Winchell, Columbia University, New York, New York; for the term 1957-60: Jackson E. TownE, Michigan State University, East Lansing, Michigan; and Walter W. Wright, Ohio University, Athens, Ohio; for the term 1957-61: Elizabeth Opal Stone, Southern Illinois University, Carbondale, Illinois; and JoHn F. Harvey, Kansas State Teachers College, Pittsburg, Kansas.

\section{Grants from the Council on Library Resources}

Grants totalling $\$ 192,400$ were announced in mid-June by the Council on Library Resources, Inc. They are $\$ 100,000$ to Rutgers University, $\$ 41,500$ to the University of Virginia, $\$ 49,500$ to the Virginia State Library.

The grant to Rutgers is to be expended over a two-year period to enable its Graduate School of Library Service to make an analytical survey of the functions and techniques of librarianship with a view toward identifying areas most likely to be susceptible to improvement through research. The grant to the University of Virginia will allow its Alderman Library to explore the application of closedcircuit television to the use of books at separated parts of the campus. The Virginia State Library will direct a study of deterioration of paper in library book-stocks and develop an inexpensive deterrent or preventative for such deterioration. ALA is enabled by its grant to send a representative to Germany to discuss international standardization of cataloging rules with the German Library Association. 


\section{ACRL at Kansas City}

Completion of ALA reorganization (and with it the organization of ACRL within ALA) highlighted the 1957 Conference at Kansas City. ACRL's statement of its fields of responsibility and the statements of the other divisions of ALA were accepted by the Special Committee on Reorganization June 25 and approved by Council June 26 .

ACRL's statement of its fields of responsibilities was approved as printed in the May issue of $C R L$ except for an amendment made by the ACRL Board of Directors at its meeting June 24. The amended item of the statement reads: "4. Representation and interpretation of college and university libraries, independent research libraries, and specialized libraries in contacts within and outside the profession through appropriate publications and other activities."

A new ACRL constitution, conforming in all details to the new structure of ALA, was voted on favorably at the business meeting of June 27. A further vote at the 1958 Conference is necessary.

Action by ALA Council made possible another major development for ACRL. On the recommendation of the Special Committee on Reorganization it approved the integration of the former Specialized Libraries Division with ACRL. To ACRL this development brings 650 additional members-from types of libraries already closely allied with college and research libraries in their aims and work. The formation of ACRL sections to represent the specific interests of these new members (law librarians, art librarians, medical librarians, and music librarians, and others) is expected at ALA's 1958 midwinter meeting.

By action of the ACRL Board of Directors immediate use of the new name of ACRL, Association of College and
Research Libraries, was authorized. The transition will be made as new printing of stationery and other items bearing the name of the Association are needed.

Recreational highlight of the week in Kansas City for ACRL members was the Wednesday lunch and tour at the University of Kansas in Lawrence. Bob Vosper and his staff extended Midwestern hospitality to more than 150 visitors.

Highlight among the ALA general programs was, of course, former President Harry S. Truman's address June 27. Outstanding among ACRL's programs was a talk by Father Paul C. Reinert, S.J., President of the University of St. Louis. Father Reinert spoke on "Problems of Higher Education."

Though the routines of an ALA Conference consumed much of the week, there was time for five programs by ACRL groups. The Rare Books Committee presented Harold Tribolet and Cecil Byrd in a session attended by more than 130. The Pure and Applied Science Section provided the special treat of a visit to the Linda Hall Library.

Dan Lacy spoke on "The College Library Today and Tomorrow" to a joint meeting of the Teacher Education Libraries Section and the College Libraries Section.

Best attended of all ACRL meetings was the panel of the University Libraries Section which presented a discussion of faculty status for librarians. The speakers were Lewis C. Branscomb, Arthur M. McAnally, and Robert B. Downs.

The Junior College Libraries Section presented a panel at its principal meeting on the subject "The Library Serves the Junior College as a Whole." The panel was led by S. V. Martorana. Other participants were Ruth E. Scarborough, Mrs. Lula K. Pratt, and Mrs. Eloise Lindstrom. 


\section{News from the Field}

\section{Acquisitions, Gifts, Collections}

The Methodist Historical Library, a collection of over three thousand books and manuscript letters, has been given to the Southern Methodist University Libraries. Included are letters from John and Charles Wesley, the Countess of Huntingdon, Francis Asbury, and other personages important in early Methodism. The collection was built by retired Bishop Frederick D. Leete and is now housed in remodeled quarters in Bridwell Library of SMU.

Fondren Library OF SOUTHERN METHODIST UNIVERSITY has been designated as a depository for Atomic Energy Commission documents.

The University of Pennsylvania Library recently acquired one of the finest collections of eighteenth century materials available, the Teerink Collection of Jonathan Swift. H. Teerink, the collector and former owner, is also a bibliographer of Swift. The collection consists of two thousand books and pamphlets. Its strength lies in the number and value of the early issues and editions of Gulliver's Travels and Tale of a Tub and in the European translations of various of Swift's books and pamphlets. It is an excellent complement to Penn's Singer-Mendenhall collection of eighteenth century novels.

Baker Library at Dartmouth College has received several valuable additions to its Robert Frost and Paul Sample collections through the Friends of the Dartmouth Library.

Over one hundred unique items were given by the late Harold Goddard Rugg, of Hanover, from his own Frost collection. All the items are either inscribed or signed by the poet or contain poems written in by him. Several valuable early Frost letters were also given by Mr. Rugg.

Paul Sample, the artist, presented ten sketch books to the library, six of them including water-color sketches done in Labrador, Iceland, the West, and New England. $\mathrm{He}$ also gave several black-and-white photographs of paintings.
The Frost collection, which is particularly rich in the poet's early letters, has been built largely through the efforts and contributions of Mr. Rugg and Mrs. Sidney Cox, widow of the late Professor Cox of the English Department. The Sample collection, undoubtedly the best in the world, exists chiefly through the generosity of the artist.

A RARE COPY OF THE FIRST EDITION OF ROBERT BURns's first book of poems has also been acquired by Dartmouth College. The first edition, limited to 621 copies, was published in Kilmarnock, Scotland, in 1786 under the title, Poems, Chiefly in the Scottish Dialect. It is now widely known as the "Kilmarnock Burns." Its acquisition remedies the only serious lack in the Dartmouth Burns collection. The copy now at Dartmouth was purchased from a London bookdealer, Charles Sawyer. The Kilmarnock contains many of Burns's most famous poems, including "The Twa Dogs," "The Cotter's Saturday Night," "To a Louse," and "To a Mouse." Almost overnight its publication gained Burns a reputation in Scotland.

NORTHWESTERN UNIVERSITY LiBRARY has acquired a copy of Juan de Mena's Todas las Obras (Antwerp, 1552). The principal poem of this work, the Laberinto de Fortuna is considered the single most important poetic work of fifteenth-century Spain.

NORTHWESTERN UNIVERSITY LIBRÁRY has acquired a beautiful set of Childe Harold's Pilgrimage in three volumes, all bound in full straight-grained crimson contemporary morocco, with blind and gilt borders, rich gilt backs and edges. Volume one is in quarto size and-according to a holograph note by its previous owner, the noted bibliographer and collector Gilbert R. Redgrave - precedes the octavo edition of the same year, 1812. This special thick-paper copy contains the poem's first two cantos. The other two volumes are the second issues of the first edition in octavo, published in London in 1816 and 1818, respectively, and containing cantos three and four. All volumes were originally issued in boards, the first 
probably re-bound by its earliest known owner, the Londesborough Library; and the other two volumes were bound by Riviere to match the first. The wide-margined pages of all volumes are clean and crisp, almost mint.

Two of THE Books NoRTHWESTERN UNIVERSITY found particularly noteworthy among recent acquisitions have in common not only that they are rare and their authors famous, but also that they are beginners' works, not written under the writers' real names. Poems, by Two Brothers (London, 1827) gives no further clue on the title page as to the brothers' identity, but was, of course, the first work of Alfred Lord Tennyson and his brother Charles. The two youngsters (Alfred was just eighteen when the volume appeared) were themselves aware that their offerings reached print prematurely and issued the book with a mixture of brazenness and trepidation, judging from the "Advertisement": ". . . and, no doubt, if submitted to the microscopic eye of periodical Criticism, a long list of inaccuracies and imitations would result from the investigation. But so it is; we have passed the Rubicon, and we leave the rest to fate; though its edict may create a fruitless regret that we ever emerged from 'the shade,' and courted notoriety." If nothing else, this selfcritical insight and honesty bestowed the mark of uncommonness upon the authors and could have presaged the greater things to come. The copy is clean and well preserved, elegantly bound in red half-morocco.

From.the Four Winds, by "John Sinjohn," is John Galsworthy's first book. It appeared in London in 1897 in sage-green, goldstamped covers and is considered hard to come by in good condition. The Northwestern copy is fine, uncut, and the dealer's cata$\log$ which advertised it states underneath a reasonable price, "A Cambridge bookseller paid $£ 125$ for a similar copy, at Sotheby's, in 1929." Galsworthy kept the name Sinjohn for his first novels, including Jocelyn (1898) until, in 1906, he published his first story of the Forsyte family, The Man of Property.

A LARGE COLlection of manuscripts, letters, notebooks, and first editions of $\mathrm{D}$. $\mathrm{H}$. Lawrence has been acquired by the Univer- sity of California Library, Berkeley, from the estate of Frieda Lawrence Ravagli, widow of the English writer. The collection will be maintained as a unit in the $\mathrm{UC} \mathrm{Li}$ brary's Rare Books Department.

Approximately fifty manuscripts, many of which have never been published, are in the collection. Among the items are manuscripts for two of Lawrence's novels: an early, unpublished version of The White Peacock (1911), and the early version, as well as the manuscript of the final version, of The Trespasser (1912). There are also manuscripts of various articles, introductions, translations, and book reviews.

In addition to the literary manuscripts, the collection contains forty-seven letters from Lawrence to Frieda Lawrence and to her mother Baronin von Richtohofen. A notebook covers details of his life in the period 1920-24, including his journeys through Sicily and Australia and finally to New Mexico, and also contains manuscript drafts of many of the poems included in Birds, Beasts, and Flowers.

Houghton Library, Harvard University, has received a collection of manuscripts, books, and pamphlets of Joel Barlow, New England poet and diplomat who died in 1812. Presented by Samuel Barlow, composer and author, the collection contains diaries, account books, letter copy books, and other personal papers. The correspondence includes exchanges with Thomas Jefferson, James Madison, James Monroe, Robert Fulton, and Noah Webster.

Mills College Library, Oakland, Calif., has received as a gift the Lillie Hitchcock Coit collection of diaries and some three thousand letters covering two centuries of American history. The earliest items, dating from the 1730 's, belonged to the James Hunter family of Virginia. Other diaries and letters described West Point cadet life in the early nineteenth century, the Seminole Indian campaign for 1839 and 1840, the Mexican War, and family life in California in the period 1851-1880. Letters and diaries of Lillie Hitchcock Coit (for whom the tower overlooking San Francisco Bay was named) concern her life in San Francisco and abroad from the turn of the century to 
1929. The collection includes letters from James Madison, James Monroe, General Nathanael Greene, Ambrose Bierce, Robert Louis Stevenson, and Joaquin Miller.

Dr. Abbie Findlay Potts, a Wordsworth scholar distinguished in England and the United States, has presented to the James Wheelock Clark Library, Russell Sage College, Troy, N.Y., her personal library of some seventy-five titles relating to William Wordsworth. The collection includes many first editions, as well as notes made by Dr. Potts while compiling her critical works about the poet. Dr. Potts is president of the Friends of Russell Sage College Library.

INDIANA UNIVERSITY LIBRARY has been given a collection of first editions, manuscripts, and other material on Joseph Conrad. The donor is Fred Bates Johnson, Indianapolis attorney.

The State Library of the New York State Education Department has been granted $\$ 50,000$ for the purchase of scientific literature and documents. Materials acquired through this program will be available on loan to colleges and universities, as well as to industrial and commercial research libraries.

A "John Erskine Fund" has been established at the Columbia University Libraries by a bequest of $\$ 15,000$ from the late Willard V. King. Income from the fund will be used for the purchase of books and other literary materials in the fields of European literature and cultural history.

Last January Mrs. Helen Worden Erskine presented to Columbia her husband's private papers and personal effects.

New York UnIVERsity has received from the Oriental Institute of Studies of the Academy of Science in Leningrad a shipment of microfilms of 160 rare Hebraic manuscripts and two Torah scrolls as part of an exchange program set up in the summer of 1956.

ThreE DIARIES and a scrapbook relating to the Civil War and later career of Royal Arthur Bensell, corporal in the California Voluntary Infantry, have been presented to the University of Oregon Library by Jay W. Dunn of Eugene.

The diaries record a daily account of military life from March 20, 1862, to October 16, 1864. The scrapbook gives accounts of Bensell's early life in eastern Iowa and of his postwar activities. The diaries have been edited and will be published by the University of Oregon.

Syracuse UnIVERSITY dedicated the Lena R. Arents rare book room of its library April 30. The room was made possible by a gift from George Arents and is a memorial to his late wife. Mr. Arents is also the donor of Syracuse's annual award for the best developed library in the senior class. Lester G. Wells is rare books librarian at Syracuse.

Dartmouth College received a copy of the rare Montgomerie Charter of the City of New York as a part of a gift of more than a hundred important literary and historical items presented to its Baker Library by Perc S. Brown.

Two rare Palestrina volumes, each in four parts, have been acquired by the University of North Carolina Library. These two volumes of motets are representative of the early and late styles of Giovanni Pierluigi da Palestrina, the great representative of Italian sacred music of the late Renaissance.

\section{BUILDINGS}

Dartmouth College has unveiled plans for a unique cultural and social center designed "to cross-fertilize the arts" on the campus. Key concept of the center, which is expected to cost about $\$ 7,000,000$, is, according to President John Sloan Dickey, "to provide through architectural design and operating organization the greatest possible exchange of stimuli, ideas, and inspirations between artists, actors, musicians, and artisans."

Plans for the center, named for Dr. Ernest Martin Hopkins, Mr. Dickey's predecessor, were first advanced in 1929. A depression, a world war, and inflated building costs prevented their being completed, however. Planning for the present group of four buildings was begun in 1955 by an advisory commit- 
tee, and completion of the project is a part of the capital gifts campaign leading to Dartmouth's bi-centenary celebration in 1969 . Construction, scheduled to start next spring, is expected to require two years.

The group of four buildings will cover an area 400 by 200 feet. The buildings will be of contemporary design, related architecturally in materials and scale to the present campus structures. The group will adjoin the Hanover Inn, facing Baker Library to the north across the college green.

GROUND-BREAKING ceremonies for a new library building at Wabash College, Crawfordsville, Indiana, were held June 8 . The librarian at Wabash College is Donald E. Thompson.

\section{Library Schools}

The University of Michigan Department of Library Science will offer two summer workshops of interest to academic and research librarians. A library buildings workshop will examine problems of library facilities and equipment in school, public, college, and university libraries. A coordinate indexing workshop devoted to "mechanizing information for research" will consider coordinate indexing and the logic of its use in manual and mechanized operations. These lectures will be integrated with a workshop investigation of the techniques involved. Both workshops will be held from August 5-16. For further information, write to the Department of Library Science, University of Michigan, Ann Arbor.

Summer Seminars given by the School of Library Science, Western Reserve University, in cooperation with the Special Libraries Association and the Cleveland Public Library, will follow up the Conference on the Practical Utilization of Record Knowledge given earlier this year. The one-week seminars will cover documentation, literature searching, and technical writing. The first group of seminars runs from July 29 to August 2; the second, from August 5-9. For precise information, write to School of Library Science, Western Reserve University, Cleveland 6.

\section{Publications}

The Chapin Library at Williams College and the Williams College Library have jointly issued Bibliographical Notes From Williams. The April, 1957, leaflet is titled "American Imprints Before 1801 in the Libraries of Williams College Not in Evans."

LIBRARIANS interested in air conditioning have available a new volume on all aspects of the subject. Although designed for architects and students and practitioners of engineering, Air Conditioning by Willis R. Woolrich and Willis R. Woolrich, Jr. (New York: Ronald Press, 1957, 384p., \$7.50) will be valuable to librarians planning new buildings or considering installing air conditioning plants.

Office Management by Charles B. Hicks and Irene Place (New York: Allyn and Bacon, 1956, 548p.) is an exhaustive treatment of fundamental practices and procedures in the field of office management. Library administrators will be especially interested in the 240-page section on simplification of office work. It covers such topics as the work simplification program, analysis of office procedures, motion economy, forms simplification and control, office layout, and office environment. Each chapter concludes with a brief summary in outline form.

THE FIRST NUMBER in the tenth series of the Emory University Library's Sources of Reprints series is a reprint of a unique copy of a rare bit of American humor, The Ups and Downs of Wife-Hunting by Kittrell J. Warren. The pamphlet includes an introduction by Floyd C. Watkins.

Handists of the 1956 Southern and Midwestern Books Competition winners are available from the Office of the Director, University of Kentucky Libraries, Lexington. A $7 \times 10$-inch self-addressed envelope with six cents postage should accompany each request.

ROBERT VOSPER, director of libraries, University of Kansas, is the author of "Books and Reading: The Librarian's Faith," in the Association of American Colleges Bulletin, XLIII (1957), 367-82. This was the 
dedicatory speech in honor of DePauw University's new Roy O. West Library building, Greencastle, Indiana, October 19, 1956. The positive role of the instructional program in relation to the library is underscored in the following passage: "An essential purpose of a liberal education such as you offer here at DePauw is, I propose, so to stimulate young people with an interest in reading that on graduation they can continue, with zest and usefulness, to read and thus to continue the process of education in adult years. There is no greater indictment of the low state of much of our so-called higher education these days than the practical illiteracy of the average college alumnus. On the other hand, there is no greater opportunity and responsibility for higher education today than the development of a literate body of alumni who have learned how to educate themselves continuously in an ever-changing world. Here the library has its dominant role in a liberal arts college."

The Virginia State Library has issued a facsimile edition of Ralph Hamor's early seventeenth-century tract on Virginia, $A$ True Discourse of the Present State of Virginia. The reprint is indexed and carries an introduction by A. L. Rowse, well known for his histories of Elizabethan England.

The Atomic Energy Commission has authorized publication of its complete file of declassified information by the Readex Microprint Corporation. In addition to AEC documents the collection encompasses material from other sources. It includes the full text of the scientific papers presented in Nuclear Science Abstracts and its predecessor, Abstracts of Declassified Documents. The Readex edition will compress the two million pages of sixty thousand documents into about sixty feet of bookshelf space.

\section{Miscellaneous}

The Midwest Academic Libraries ConFERENCE held its second annual meeting in Milwaukee May 11 and 12 with approximately 150 librarians present. Chairman of the 1957 conference was Ben B. Richards of Knox College. Host institution was Marquette University. Will B. Ready of Mar- quette, Robert B. Downs of the University of Illinois, and Ralph Esterquest of the Midwest Inter-Library Center were speakers. H. Vail Deale of Beloit College is chairman of the MALC for 1957-58. Next year the MALC will meet at Southern Illinois University, Carbondale, on April 25 and 26. The new library of SIU will hold its dedication ceremonies at that time.

INTERLIBRARY COOPERATION was the subject of the meeting of the Philadelphia chapter of ACRL, which was held at the University of Pennsylvania in May. Speakers were Flora B. Ludington (on the Hampshire Interlibrary Center), Harry Dewey (on the Midwest Inter-Library Center), and Eleanor Campion (on the Philadelphia Bibliographical Center.)

John A. Lester, Jr., of Haverford College succeeds Martha A. Connor as president for 1957-58. Mrs. Flora Deibert Colton of the University of Pennsylvania was elected vicepresident (president elect). Robert Taylor of Lehigh University was elected secretarytreasurer.

W. Stanley Hoole, director of libraries of the University of Alabama, delivered the keynote address for the Alabama Library Association on April 12. The major portion of that address has since been printed as an editorial in the Saturday Review for June 7.

Currently showing at the Lakeside Press Galleries, Chicago, is an exhibition of the work of famed designer Bruce Rogers. It will remain on view through July.

The COLlege AND UNIVERSITY SECTION of the Virginia Library Association met at Mary Washington College of the University of Virginia, Fredericksburg, May 18.

The University of North Carolina television station WUNC-TV closed its spring series of "Books and People," a program sponsored by the University library, with its sixty-fifth program in the series. Program 64 , May 21, was an interview conducted by Lambert Davis of the University of North Carolina Press with Robert B. Downs on Louis Round Wilson's new The University of North Carolina, 1900-1930: The Making of a Modern University. 


\section{Personnel}

Jerrold OrNe has been appointed librarian at the University of North Carolina, and will assume his duties at Chapel Hill beginning August 1. Since 1951 he has been di-

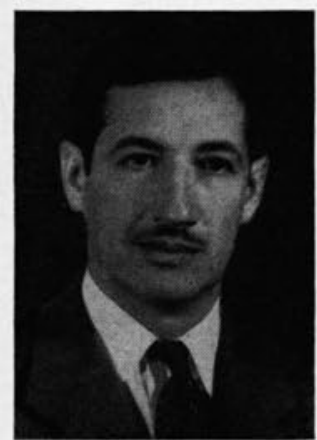

JERrold ORNe rector of libraries at the Air University, Maxwell Air Force B a se, Montgomery, Alabama.

Born at St. Paul, Minnesota, in 1911, he received A.B. and M.A. degrees from the University of Minnesota in 1932 and 1933 respectively, his Ph.D. in romance linguistics from the University of Chicago in 1939, and a B.S. in library science from the University of Minnesota in 1940. He also studied for a year at the Sorbonne, in Paris.

After serving with the Navy from 1943 to 1946 (in 1945 he was chief of the libraries division of the U.S. Commerce Department's Office of Technical Services), Jerrold Orne was for five years director of libraries at Washington University, St. Louis, Missouri. Earlier he held positions with Knox College, in Galesburg, Illinois; the University of Chicago, and the St. Paul Public Library. He was at the Library of Congress during $1940-41$ as a fellow in library science and romance languages, where he made a series of surveys and recommendations regarding the library's facilities, and directed special operations, such as the storage of books and manuscripts at the outbreak of war.

Mr. Orne has served as editor of the Missouri Library Association Quarterly, Washington University Library Studies, and American Documentation (associate editor) and is the author of "Subject Headings for Technical Libraries" (1947), "The Language of the Foreign Book Trade" (1949), "El Futuro de la Biblioteca en Cuba" (1950), and other works. He was chairman of ACRL's Publications Committee 1954-57.
The PeABody Institute of Baltimore seems to be establishing a tradition of having librarians who are especially interested in maps. Lloyd Brown was well known for his publications and exhibits in this field. His successor, Frank N. Jones, who took office June 1, also has cartographic interests and was the principal founder of the Cartophile Society, which has been active in Boston since 1947.

A native of Pennsylvania, Frank Jones graduated from Harvard in 1930. He worked with Milton Lord at the Boston Public Library, with C. C. Williamson at Columbia, and with Keyes Metcalf at Harvard before becoming librarian of Ohio University at Athens in 1949. At Ohio, he emphasized bringing books and students together by introducing the open stack system, establishing a browsing room and dormitory libraries, and placing a student representative on the library committee. In 1953-54 he served as president of the Ohio Library Association.

$\mathrm{He}$ also took an active interest in the history and archives of the university, the oldest in the Old Northwest, and participated in the establishment of the Ohio University Press during the university's sesquicentennial year, 1954. Now he goes to another historic institution in the midst of another anniversary celebration. Frank Jones's wide experience fits him well to bring new dimensions to the special service which the hundred-year-old Peabody Institute renders to the people of Baltimore.-Foster M. Palmer.

Phyllis Bull Dalton became assistant California state librarian March 18. In the nine years since Mrs. Dalton came to the California State Library from the University of Nebraska Library, where she was assistant librarian for humanities, she has progressed steadily through all of the professional librarian civil service levels to her present post. Two of her major activities before becoming assistant state librarian were the organization and development of the state library's Administrative-Legislative Reference Section, and the establishment and coordination of the Reader Service Bureau, with direction of all six of the library's 
reader service sections: Reference, Law, Administrative-Legislative Reference, California, Government Publications, and the Sutro Library in San Francisco. She is a graduate of the University of Denver School of Librarianship.

Mrs. Dalton continues as a member of the State Library's Administrative Committee, which consists of the principal librarians for Reader and Technical Services, chief library consultant, assistant state librarian, and state librarian.

Mrs. Dalton's promotion set off a chain of promotions unprecedented in California State Library history. Beulah Mumm, supervising reference librarian, has been appointed as principal librarian, Reader Services. Constance LeE, supervising government publications librarian, has transferred to become supervising reference librarian. Melvin OAThout has been promoted from supervisor of Administrative-Legislative Reference Service to supervising government publications librarian. Charles Mastin has been promoted to Supervisor of Administrative-Legislative Reference.

\section{Appointments}

Manuel Alcala is director of the library of the Universidad Nacional Autónoma de México, which has just moved into a handsome new building.

Vibeke Ammundsen, formerly associated with the Veterinaerog Landbohöjskolens Bibliotek, succeeds the late Arne Möller as director of Denmark's Tekniske Bibliotek.

H. Richard Archer, formerly librarian of R. R. Donnelley in Chicago, is now librarian of the Chapin Library, Williams College.

MARY Jo Austin is on the reference staff of Emory University Library.

Paul Berrisford is now chief catalog librarian, University of Minnesota.

Henry Birnbaum is circulation librarian, Brooklyn College Library.

GEORGE K. Boyce is catalog librarian, Law Library, University of Michigan.

Robert S. Bray, who has been chief of the Technical Information Division, is now chief of the Division for the Blind at the Library of Congress.

Robert W. Bullen joined the West Virginia Library Commission July 1 as a consultant. He was formerly at Mississippi State College.

William H. Carlson, director of libraries, Oregon State System of Higher Education, is on sabbatical leave June through September. Carl W. Hintz is serving as acting director.

Frances Laverne Carroll is librarian of Coffeyville College Library, Coffeyville, Kansas.

James R. Cox is geology librarian at UCLA.

Vincent H. Duckles, librarian of the Music Library and lecturer in music bibliography at the University of California, Berkeley, has been awarded a Fulbright research grant for the coming year at the Institute of Musicology, University of Göttingen, Germany.

Lucy Duxe is librarian of the School of Business Administration of Emory University.

Dorothy Harbin is assistant serials librarian at Emory University.

Robert D. Harlan is head of the book order section, University of Michigan Library.

George H. Healey of the Cornell University English department became curator of rare books for the Cornell University Library July 1.

Ray E. Held is assistant professor in the School of Librarianship of the University of California, Berkeley. 
Wilbur Helmbold became librarian of Howard College, Birmingham, Alabama, May 1.

David W. Heron will become associate librarian of the Hoover Institute and $\mathrm{Li}$ brary September 1. Mr. Heron has been acting associate director of the Stanford University Libraries since September, 1955.

W. Stanley Hoole, director of libraries of the University of Alabama, has been appointed research consultant to the Subcommittee on Special Education of the United States House of Representatives. The subcommittee will concern itself chiefly with legislative problems of college and university education.

Miles Horton is general reference librarian, Virginia Polytechnic Institute, Blacksburg, Virginia.

Mary Elizabeth Hughes became documents librarian of Stanford University February 1 .

JAMES Humphry, III, librarian, Colby College, Waterville, Maine, has been appointed librarian of the Metropolitan Museum of Art in New York.

W. CARL Jackson is assistant professor and chief acquisitions librarian, University of Minnesota Library. $\mathrm{He}$ was formerly in a similar position at the State University of Iowa Library.

LEONARD R. JoHnson has been appointed cataloger at the Olin Library, Wesleyan University, to begin September 1 .

JAMES Kingsley, JR., is assistant professor and chief bibliographer at the University of Minnesota Library. His primary responsibility will be in the area of the library's resources, with specific concern for relations with the Midwest Inter-Library Center, decisions of weeding, transfer and selection of material for storage, and related problems.

Carl H. Koopman, librarian of The Citadel, Charleston, S. C., was designated department head of The Citadel Library, January $1,1957$.

FANG-JEN Li is a cataloger at Michigan State University.
John David Marshall, reference department, Alabama Polytechnic Institute Library, Auburn, Alabama, has accepted an appointment at UCLA beginning August 1 .

EVERETT T. MOore, reference department, UCLA, is teaching in the summer school of the University of Washington School of Librarianship.

Jesse C. Mills, recently head of circulation at the University of Pennsylvania Library, is assistant librarian, service division, succeeding Walter W. Wright.

Frances Muse is librarian of the Technical Reference Library of the Georgia Power Company, Atlanta.

Julian Motta Salas is director of the Biblioteca Nacional in Bogotà.

Nahum M. Sarna will become librarian of the Jewish Theological Seminary of America September 1. He will succeed Rabbi Gerson D. Cohen.

Benton Scheide is now director of libraries and museums, State Teachers College, Kirksville, Missouri.

Daniel A. Seager, formerly head librarian of Ouachita College, Arkadelphia, Arkansas, is now head librarian of Colorado State College, Greeley.

Jagdish S. Sharma, formerly research officer and librarian, Indian National Congress, New Delhi, India, became librarian, Banaras Hindu University, Banaras (U.P.), India, September 1, 1956. Dr. Sharma is also in charge of the courses in Library Science offered at Banaras Hindu University. $\mathrm{He}$ teaches reference, bibliography, and library organization.

Paul Spence is director of the library, Air Force Institute of Technology, WrightPatterson Air Force Base, Ohio.

Eula Windham is circulation and reference librarian at Hardin-Simmons University, Abilene, Texas.

Dorothy Young is librarian of the Servo Corporation of America, New Hyde Park, New York. 


\section{Retirements}

"Emerita" is an honored word, yet the retirement of Clyde Elaine Pettus from active teaching brings new honor to it. Miss Pettus closes a career of thirty-five years of teaching cataloging at the Emory University Library School with the completion of this academic year. On May 31 her university and library friends from all over the Southeast met at Emory to honor her with a dinner and to present her with a gift as a token of their continuing regard and affection.

The bare bones of biographical listings do not catch the spirit that has animated Miss Pettus as a librarian and made her a memorable teacher. One finds there the appropriate degrees (A.B., Agnes Scott, 1907; A.M., Emory, 1927; A.M.L.S., Michigan, 1931), the scholarly recognition (Phi Beta Kappa), the record of professional contributions through publications, the list of positions (Brooklyn, Knoxville, Atlanta, Emory). But one cannot find there the air of quiet efficiency that dominated her classes. One cannot find there the aura of shy, but firm and honest, friendliness that was always with her-in class and away from it.

Not always was there time for Miss Pettus to reveal her incisive, yet gentle, wit to her classes. A student could study through the Emory Library school without knowing of her wide cultural interests or her particular delight in children's books. How could a teacher obviously so completely devoted to her work have time for other interests? But she did, and the fullness of those interests guarantees her continued interests and enjoyment in her years of retirement.-Richard Harwell.

Georgia Hicks Faison, who retired July 1 as reference librarian after thirty-three years of service to the University of North Carolina, left Chapel Hill this spring for a tour of Europe. This trip was a gift to Miss Faison from her many friends among the faculty, students, and alumni of the University of North Carolina. A check to cover expenses for her European trip was presented to Miss
Faison in a ceremony November 15, which was attended by the chancellor and many other well-wishers.

Reference librarian since 1928, Miss Faison came to the university library as head of the Circulation Department in 1924, when the university had a student body of 2,300 and the library collection numbered 175,000 . Before entering the library profession, Miss Faison had taught Latin, history, and mathematics for seven years in various North Carolina school systems.

In 1919, Miss Faison went to Brooklyn for library training at Pratt Institute of Library Science. Later she earned a degree in Library Science at the New York State Library School, in Albany. She was a cataloger at the Yale University Library for a year and a half, and librarian at Randolph-Macon Woman's College for two years.

Miss Faison's work as reference librarian has paralleled closely the growth of the university's Graduate School and the growth of the library collection. She has always believed strongly that the library must play an integral part in the instruction and research programs of the university and has never missed an opportunity to help bring this about. She has had, almost daily, through the years, consultations and discussions with faculty members and graduate students in her effort to help make available the materials needed for graduate work and research. Her close cooperation with librarians in other universities helped to set up the interlibrary loan system.

Although much of her time and effort has been given to building up the collection for research and in helping graduate students and faculty with their problems, Miss Faison has taken considerable interest in the undergraduate and his use of the library. The present system of two hours of instruction required of each freshman who has not passed a screening test was started by the Reference Department in 1949. The undergraduate, as well as the more advanced student, has been made to feel that he can expect understanding and willing assistance 
when he brings his problems to the Reference Department.

Librarians and students in library science are often grateful for the years of work which went into the preparation of the $A L A$ Glossary of Library Terms, Chicago, 1943, prepared by the ALA Committee on Library Terminology, of which Miss Faison was chairman from 1936 to 1938 . Knowing that much groundwork was done in the thirties on the ever-present problem of a clearing house or union list of German dissertations, we were interested to read Miss Faison's proposal on "The Care of German Dissertations" in the ALA Bulletin for July, 1936. It is gratifying to learn that out of such thought and planning by many librarians, there is now the Midwest Inter-Library Center plan for a centralized depository of German dissertations.

Miss Faison has been an enthusiastic member of the Southeastern Library Association, taking part in many discussions in the College and University Libraries Section. In 1947, she reported on "Reference Service in College and University Libraries in the Southeast" at the conference. This paper was included in the Papers and Proceedings of the Twelfth Biennial Conference. In 1951, she served as secretary of the College and University Section of SELA. Last fall, at the 1956 Roanoke meeting of the Southeastern Library Association, Miss Faison was a member of Dr. Kuhlman's panel which discussed the place of the library in the instructional program of the university.

She has been an active and interested member of the North Carolina Library Association, serving on various committees at different periods. An occasional contributor to the official publication, she wrote a delightful article on "Humor, a Librarian's Asset" in North Carolina Libraries for October, 1952.

The library staff and other bibliographers still find useful the two chapters which Miss Faison contributed to the University of North Carolina Sesquicentennial Publication, Library Resources of the University of North Carolina (1945).-Pattie B. McIntyre.

Lydia M. Gooding, curator of the Annmary Brown Memorial and assistant professor of bibliography at Brown University, retired June 30. Miss Gooding joined the Brown library staff in 1946 as librarian of Pembroke College, and before her appointment as curator of the Annmary Brown Memorial in 1954 worked at the John Hay Library at Brown. Before going to Brown she had worked in the libraries of Dickinson College and Princeton University and had taught at the Emory University Library School. She is a graduate of Dickinson College and holds bachelor and master of science degrees from the Columbia University School of Library Service.

MARY Vick BURNEY has retired as librarian of the University of Tennessee Junior College, Martin, and is living in Denton, Texas.

Mrs. Vera Southwick Cooper has retired as librarian of DePauw University, Greencastle, Indiana.

\section{Necrology}

NATHANiel Lewis GoodRich, 77, librarian of Dartmouth College for 38 years, died April 30.

Mr. Goodrich, born in Concord, N. H., February 9, 1880, became head of the old Dartmouth Library in Wilson Hall in 1912. He supervised the library's move into new quarters in Baker Library in 1928, and administered its vast expansion in the years following. He was made a full professor in 1943 and retired in 1950, becoming librarian emeritus.

Graduated from Amherst College in 1901,
Mr. Goodrich received a B.L.S. degree at the New York State Library School in 1904. He served as librarian of West Virginia University and the University of Texas before joining the Dartmouth staff.

During World War I, he served as a captain of military intelligence with the General Staff in Washington.

Mr. Goodrich was an avid skier, mountaineer, and outdoorsman. He pursued these interests in travels in North America and Europe.

At the time of his retirement, he was re- 
garded as the dean of New England college librarians. Dartmouth conferred an honorary Master of Arts degree on him in 1920, and Amherst awarded him a Doctorate of Letters in 1941.

Mrs. Josephine Halverson Morris, head of technical processes, Colorado State University, Fort Collins, died after an illness of several months June 12, 1957. She was graduated from the University of California and later received a certificate in librarianship from the library school there. While on the staff at Colorado State College of Education she secured an M.A. in English. After service at the University of California Library, Oregon State College, and the University of Idaho she went to Colorado State College of Education at Greeley on a recataloging project, later becoming assistant librarian, and librarian. She resigned to be married to David W. Morris in the summer of 1952. In January of 1954 she became head of technical processes at Colorado State University, serving until she took leave for illness in January of 1957.

From 1943 to 1948 she was chairman of the Colorado College and Head Librarians Conference, and from 1944 to 1947 she was secretary of the council and a member of the executive committee of the Bibliographical Center for Research, Denver. During 1952 she was vice-president of the Colorado Library Association. During 1956 she was an active member of the special faculty committee to select a new director of libraries for Colorado State University and helped with the selection duties even while on sick leave. An unusually conscientious and devoted librarian, she had nearly completed the reorganization of the technical process of CSU, and the value of the work she did there will be felt for many years to come.-James G. Hodgson.

IsAdORE GILBERT MUdGe, whom many called "the outstanding reference librarian of the country," died May 16 at the age of eighty-two. Through the years her name has become almost synonymous with reference work and reference books. After graduating from Cornell University in 1897 and from the New York State Library School in 1900, she became reference librarian and assistant professor of library science at the University of Illinois, 1900-1903; librarian of the Bryn Mawr College Library, 1903-1908; instructor in library science at Simmons College, 19101911; and reference librarian at Columbia University from 1911 until her retirement thirty years later in 1941. She was also associate professor of biblography in the Columbia School of Library Service from 1927 to 1938 .

It was at Columbia that her career and reputation advanced along three interwoven lines. She was, first of all, a reference librarian, but she was also a distinguished teacher, author, and editor. She built up one of the great reference and bibliographical collections of the country, and, with almost uncanny knowledge and skill, she used these materials to aid both faculty member and student. Among those who called upon her most frequently was President Nicholas Murray Butler. Of the questions which he asked, many were concerned with the location of quotations. Two of these which Miss Mudge considered especially appropriate she adopted as mottoes for the Reference Department: "Verify our title" and "God Almighty hates a Quitter." To this day, the rule is that all titles asked for at the reference desk must be verified and, in some cases at least, the second quotation spurs on the search.

Her teaching was both formal and informal, and ranged from instructing a beginning graduate student in the use of indexes to teaching a well-organized course in advanced bibliography in the School of Library Service. The many students who from 1927 to 1938 took this course will attest to the thorough training in bibliographic technique which they received. Some of her most useful teaching was in graduate seminars, where she introduced students to bibliographies and source materials in various subject fields, and many Columbia Ph.D.'s have expressed the opinion that this instruction was one of the most valuable experiences in their early professional careers.

Much of Miss Mudge's fame rests upon her Guide to Reference Books, which she compiled four times from 1917 to 1936, with intervening supplements. Through these years "Mudge" was the vade-mecum of li- 
brarians and library school students, the latter often speaking of "mudging" as they worked their way through assignments in bibliographies and indexes.

Miss Mudge's interests, however, were not confined to the purely professional aspects of her work. She and Minnie Earle Sears bought, and converted into an attractive and most livable home, a pre-Revolution carriage house, with hand-hewn beams and oakpaneled walls. The house stood at the top of a sloping pear orchard, and here she most thoroughly enjoyed the delights of gardening, for her thumb was "greener" than most. Under the pear trees she set out daffodils, so that each spring the hillside was literally covered with thousands of yellow and white blossoms. During World War II, she conceived the idea of selling these daffodils for war relief. With the help of a committee of faculty wives, the flowers were picked and brought in to the Columbia campus, where they were sold for twenty-five cents a dozen. Tradition says that in the course of one spring some 15,000 blossoms were sold and, as the custom has continued through the years, more than $\$ 4,000$ has been raised for war and community relief.

In her profession, Miss Mudge's name and fame have become almost a legend and the library world has indeed lost a great librarian, while I who worked closely with her for more than fifteen years have lost a guide, mentor, and friend. However, I like to realize that the influence of her gifts as librarian and teacher will remain not only with me, but with countless others through the years to come-Constance $M$. Winchell.

Henry R. Wagner (1862-1957), one of the fabulous figures of the book world-bibliographer, collector, cartographer, historiandied at the age of 94 on March 27, 1957. Henry R. Wagner lived nearly a century; and yet it is amazing that one man should have done as much as he did in so short a time. I was one of the lucky men who knew him personally, one of the dozens of young history graduate students (that was nearly twenty years ago in my case) he befriended, inspired, and welcomed to his home for book talk and refreshments.

There are eulogies and serious tributes to Wagner appearing in library and book trade publications every week now. The Wagner legend will continue to grow and it will not be exclusively bookish. Some of it will be lustily humorous. $\mathrm{He}$ and I had a little joke in which we both delighted. One afternoon early in our acquaintance I called on him when he had been relaxing, in his slippers and with his dentures on a near-by smoking stand. After we had talked a bit, he stopped abruptly and exploded, " $\mathrm{G}$ D- it, Horn, hand me my teeth so you can understand what I'm telling you!" $\mathrm{He}$ didn't just laugh when I jumped. He fairly roared with pleasure. By this little passage he told me for all time to quit thinking about him as the Henry R. Wagner and get my mind on the business we were discussing. No doubt, other friends had the same trick played on them by HRW; but from time to time later, when he said "hand me my teeth," I knew he meant "now listen carefully." It was never dull to listen to that man.-Andrew H. Horn.

Nelle Barmore, librarian of the Communicable Disease Center of the U. S. Public Health Service in Atlanta, died in Atlanta February 15. She had been continuously active in library work since 1922.

Carrie Lougee Broughton, former state librarian of North Carolina and associated with the North Carolina State Library for fifty-four years, died January 29.

John Doyle Caylor died at Fort Benning, Georgia, December 19, 1956. He had just completed his work in the Emory University Library School and had accepted a position at the U. S. Naval Academy, Annapolis. He was an alumnus of the Naval Academy.

Wilmer L. Hall, state librarian of Virginia from 1934 to 1946 , died January 25.

Lou S. SHine, a member of the staff of the University of North Carolina Library from 1937 until 1953, died January 12.

Franz Wieland, formerly librarian in the University of Tübingen Library, died April 1 , at the age of eighty-four. 